\title{
Activated Charcoal-A Potential Material in Glucoamylase Recovery
}

\author{
S. O. Kareem, ${ }^{1}$ I. Akpan, ${ }^{1}$ T. O. S. Popoola, ${ }^{1}$ and L. O. Sanni ${ }^{2}$ \\ ${ }^{1}$ Department of Microbiology, University of Agriculture, PMB 2240, Abeokuta, Nigeria \\ ${ }^{2}$ Department of Food Science and Technology, University of Agriculture, PMB 2240, Abeokuta, Nigeria
}

Correspondence should be addressed to S. O. Kareem, sharafkareem@yahoo.co.uk

Received 28 April 2011; Revised 20 September 2011; Accepted 21 September 2011

Academic Editor: J. Guisan

Copyright (C 2011 S. O. Kareem et al. This is an open access article distributed under the Creative Commons Attribution License, which permits unrestricted use, distribution, and reproduction in any medium, provided the original work is properly cited.

\begin{abstract}
The potential of activated charcoal in the purification of fungal glucoamylase was investigated. Various concentrations of activated charcoal $(1-4 \% \mathrm{w} / \mathrm{v})$ were used to concentrate crude glucoamylase from Rhizopus oligosporus at different temperature values (30$\left.50^{\circ} \mathrm{C}\right)$. Effects of $\mathrm{pH}(3.0-6.0)$ and contact time $(0-60 \mathrm{~min})$ on enzyme purification were also monitored. Activated charcoal $(3 \% \mathrm{w} / \mathrm{v})$ gave a 16 -fold purification in a single-step purification at $50^{\circ} \mathrm{C}$ for $20 \mathrm{~min}$ and $\mathrm{pH}$ 5.5. The result of SDS-PAGE analysis of purified glucoamylase showed two major protein bands with corresponding molecular weight of $36 \mathrm{kDa}$ and $50 \mathrm{kDa}$. The method is inexpensive, rapid, and simple which could facilitate downstream processing of industrial enzyme.
\end{abstract}

\section{Introduction}

Enzyme purification is a necessary prerequisite for a full understanding of the nature and mechanism of action of the enzyme [1]. This is usually carried out by a multistep process involving biomass separation, concentration, primary isolation, purification, and polishing as the main unit operations [2]. The conventional methods for the removal of colloidal particles and enzymatic impurities from fermentation broth using ammonium sulphate precipitation may require extensive dialysis for about $12-16$ hour for product recovery and often cause protein denaturation due to conformational changes [3]. The use of carbowax or polyvinyl alcohol for protein and enzyme concentration is also limited by poor water absorbing capacity [4]. Similarly, the use of carboxy-methyl cellulose, tannic acid, and edible gum as precipitants and as well as organic solvents also poses the problem of product recovery $[5,6]$. Gel filtration technique is also considered laborious and expensive in the developing countries $[6,7]$.

Activated charcoal is an adsorbent widely used in the treatment of wastewater and industrial contaminants by virtue of its high removal capacity and adaptability for a wide range of pollutants [8]. It is made from any essentially carbonaceous materials. Tree bark, coal, cotton waste, palm kernel shell, and many agricultural by- products can be used to produce activated carbon and their ability to remove colours have been reported [9].

Activated charcoal is used to remove compounds that cause objectionable taste, colour, and odour in water treatment while its industrial applications involve removal of toxic gases and pesticides and as well as purification of organic compounds $[10,11]$. It is known that around $80 \%$ of the world production of activated charcoal is used in aqueous-phase adsorption of both organic and inorganic compounds [12, 13]. Although application of activated charcoal in the decolorization of enzyme-converted glucose syrup had been reported, its uses in the purification of microbial enzymes have been scanty. This study reports application of activated charcoal in the recovery of fungal amylases.

\section{Materials and Methods}

2.1. Microorganism. Amylolytic strains of Rhizopus oligosporus were obtained from the culture collection center, Department of Microbiology, University of Agriculture, Abeokuta, Nigeria. It was maintained on potato dextrose agar (PDA) slants at $4^{\circ} \mathrm{C}$ and subcultured bimonthly. 
2.2. Chemicals. Activated charcoal, 3, 5-dinitrosalicylic acid and polyacrylamide were from Sigma. All chemicals were reagent grade.

2.3. Amylase Production. Rice bran solid-state medium was prepared and inoculated with spores of Rhizopus oligosporus according to the method of Akpan et al. [14]. Incubation was at $30^{\circ} \mathrm{C}$ for $72 \mathrm{~h}$. The crude amylase was recovered by mixing the moldy bran. Moldy bran was mixed with acetate buffer $(0.2 \mathrm{M})(\mathrm{pH} 4.5)$ in the ratio $1: 4(\mathrm{w} / \mathrm{v})$ in a conical flask. The mixture was shaken on an orbital shaker at $150 \mathrm{rpm}$ at $28^{\circ} \mathrm{C}$ for $1 \mathrm{~h}$. The extract was then filtered using muslin cloth. The filtrate was used as the crude amylase and kept at $4^{\circ} \mathrm{C}$.

2.4. Determination of Amylase Activity. The amylase activity was determined by mixing crude amylase with $4 \% \mathrm{w} / \mathrm{v}$ gelatinized cassava starch $(\mathrm{pH} 4.5)$ and incubated at $60^{\circ} \mathrm{C}$ for $1 \mathrm{~h}$. Reducing sugar was determined using dinitrosalicylic acid method of Miller [15]. Protein concentration was estimated using biuret method as described by Koch and Putnam [16].

2.5. Purification of Crude Amylase with Activated Charcoal. Studies were carried out on the purification of glucoamylase using activated charcoal $(0.8 \mathrm{~mm})$. Various concentrations of activated charcoal $(1-4 \% \mathrm{w} / \mathrm{v})$ were added to crude glucoamylase $(\mathrm{pH} 4.5)$ and incubated at $30^{\circ} \mathrm{C}$ for $30 \mathrm{mins}$ with occasional stirring. The mixture was then centrifuged at $2500 \mathrm{rpm}$ in a bench centrifuge for $10 \mathrm{~min}$. The effect of temperature on enzyme purification capacity of activated charcoal was evaluated at different temperature values (30$60^{\circ} \mathrm{C}$ ). Effect of $\mathrm{pH}$ on the purification of glucoamylase was also determined at different $\mathrm{pH}$ values (3.5-6.0).

2.6. Electrophoresis. Molecular weight of the purified enzyme was estimated using Sodium dodecyl sulphate (SDS) polyacrylamide gel electrophoresis as described by Laemmli [17]. The gels were stained with Coomassie Brilliant blue R250 (BioRad, USA). The protein bands were estimated and compared with standard protein markers (BioRad, USA).

\section{Results and Discussion}

3.1. Effect of Concentration of Charcoal. The result presented in Figure 1 showed the effect of various concentrations of activated charcoal on the purification of fungal amylase. A significant increase was noted in the specific activity of the glucoamylase as the concentration of charcoal increases up to $3 \% \mathrm{w} / \mathrm{v}$ with the optimum-specific activity of $250 \mathrm{U} / \mathrm{mg}$. A further increase beyond $3 \%(\mathrm{w} / \mathrm{v})$ led to a decrease in their specific activity. About $90 \%$ reduction in turbidity was observed in the treated sample. It was observed that the rate of absorption changed in magnitude with the increase in the amount of charcoal used. The degree of absorption has been reported to be influenced by accessibility of the adsorbate to the adsorbent [18].

3.2. Effect of Temperature on Amylase Purification. The result presented in Figure 2 summarized the effect of time and
TABLE 1: Effect of $\mathrm{pH}$ on purification of glucoamylase by activated charcoal.

\begin{tabular}{cccc}
\hline $\mathrm{pH}$ & $\begin{array}{c}\text { Amylase activity } \\
\mathrm{U} / \mathrm{mL}\end{array}$ & $\begin{array}{c}\text { Protein conc. } \\
\mathrm{mg} / \mathrm{mL}\end{array}$ & $\begin{array}{c}\text { Specific activity } \\
\mathrm{U} / \mathrm{mg}\end{array}$ \\
\hline 3.0 & 1430 & 14.16 & 101 \\
3.5 & 1478 & 9.60 & 154 \\
4.0 & 1598 & 8.83 & 181 \\
4.5 & 1675 & 3.57 & 469 \\
5.0 & 1684 & 3.20 & 526 \\
5.5 & 1686 & 3.38 & 496 \\
6.0 & 1640 & 3.87 & 424 \\
\hline
\end{tabular}

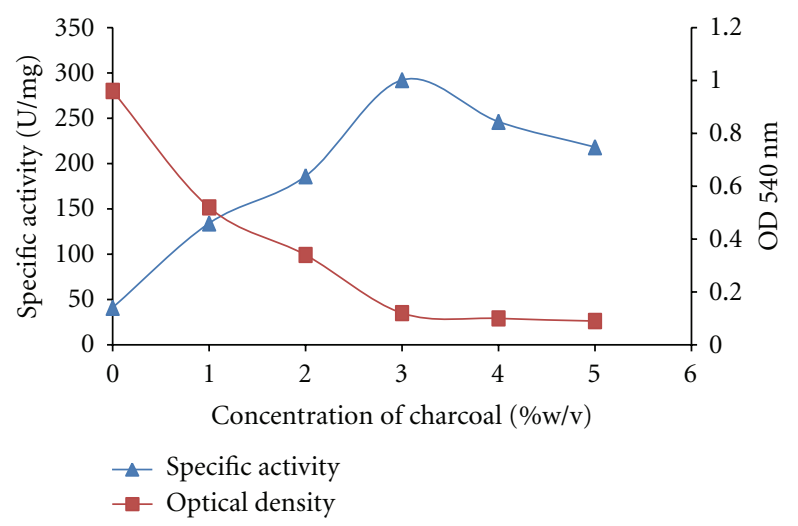

Figure 1: Effect of concentration of activated charcoal on purification of glucoamylase.

temperature on the purification of amylase using activated charcoal. It was evident that purification of fungal amylase by charcoal at elevated temperatures gave a marked increase in the specific activity of fungal amylase. At $50^{\circ} \mathrm{C}$, optimum specific activity of $520 \mathrm{U} / \mathrm{mg}$ was attained at 20 min resident time. However, enzyme treatment with charcoal at temperature beyond $50^{\circ} \mathrm{C}$ and at a longer period beyond $30 \mathrm{~min}$ resulted in a decrease in amylase activity. It is evident that elevated temperature enhanced protein absorption and decolorizing capacity of activated charcoal. The rate and capacity of absorption depends mainly on the surface chemistry of activated charcoal, contact time, and temperature $[8,19]$.

3.3. Effect of $p H$ on Glucoamylase Purification. Table 1 showed the effect of $\mathrm{pH}$ on the purification of fungal glucoamylase by activated charcoal. It was observed that $\mathrm{pH}$ values between 4.5 and 5.5 enhanced the specific activity of the fungal amylase with optimum purification index at $\mathrm{pH}$ 5.5. However, at $\mathrm{pH} \geq 5.5$ there was a decrease in the specific activity of the enzyme. This paper conforms with optimum $\mathrm{pH}$ range for amylases [20]. Ability to purify the amylase at $\mathrm{pH}$ 4.0-5.5 which falls within the optimum $\mathrm{pH}$ values for amylase is also an added advantage.

3.4. Purification of Glucoamylase under Optimized Conditions. Purification profile of glucoamylase with charcoal under 
TABLE 2: Summary of purification of glucoamylase.

\begin{tabular}{|c|c|c|c|c|c|}
\hline Steps & Amylase activity U/mL & Protein mg/mL & Specific activity U/mg & Purification fold & Yield \% \\
\hline Crude amylase & 1702 & 50 & 33 & - & 100 \\
\hline Activated charcoal & 1684 & 3.2 & 526 & 16 & 81 \\
\hline
\end{tabular}

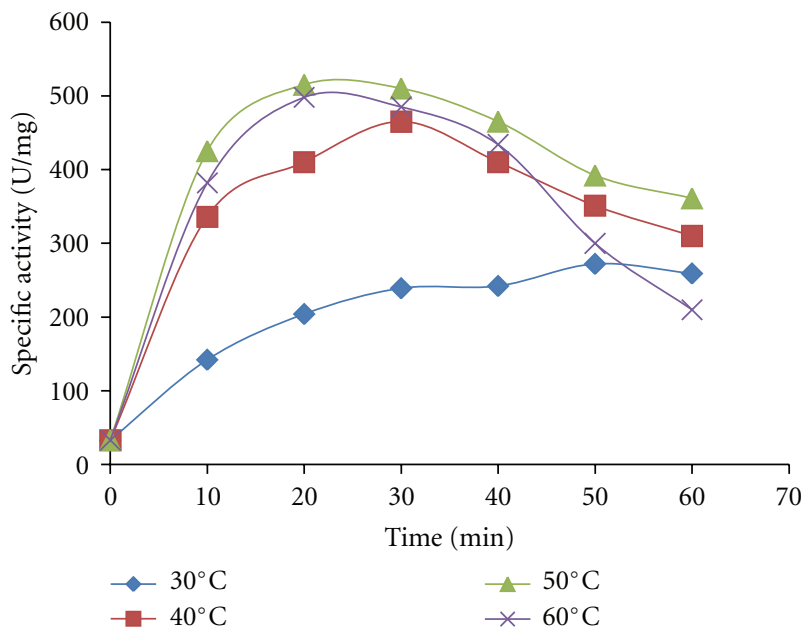

FIGURE 2: Effect of temperature on purification of glucoamylase using activated charcoal $(3 \% \mathrm{w} / \mathrm{v})$.

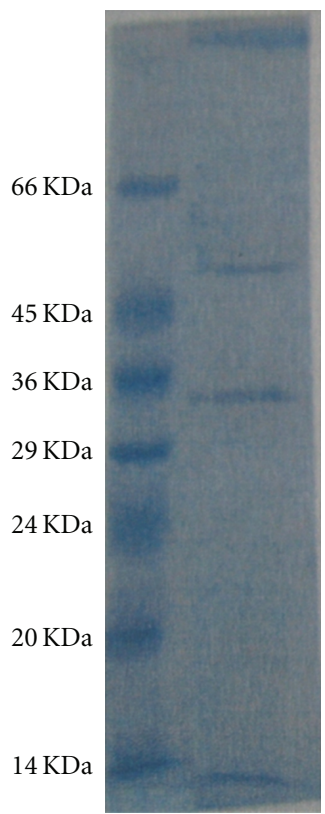

FIgURE 3: Molecular weight of purified glucoamylase on SDS-PAGE gel.

optimized conditions gave a 16 -fold purification in a single step (Table 2). The result is a marked improvement over the conventional method of enzyme purification such as ammonium sulphate precipitation. Interestingly, the glucoamylase was left in the supernatant and the effectiveness of activated charcoal at low concentration had been noted as an added advantage at $\mathrm{pH}$ 4.5. The fact that enzyme does not precipitate with activated charcoal may be due to the selective absorption of proteins which is attributed to fine network of pores, distribution of pore sizes, the type of functional group on the surface, contact time, and temperature $[8,19]$.

Rapid purification of enzyme from a complex fermentation broth mixture at a high purification fold put activated charcoal at an advantage over conventional purification techniques. The conventional methods of enzyme purification including salting out technique, solvent precipitation, and gel filtration are not always economical from an industrial stand point because, they are associated with some problems particularly such as difficulty of scaling up and plugging when treating crude extracts which often contain viscous and particulate materials $[18,21]$. Furthermore, recovery or disposal of materials used in the separation process may increase the cost of the separation step, and therefore, it is expensive for developing economy [19]. Therefore, the use of activated charcoal is considered as alternative method of enzyme purification. The result of SDS-PAGE analysis of purified glucoamylase (Plate 1) showed two major protein bands with corresponding molecular weight of $36 \mathrm{kDa}$ and $50 \mathrm{kDa}$ which falls within apparent molecular weights for fungal glucoamylases (see Figure 3) [18].

Efficient surface absorption characteristics in addition to the low cost of activated charcoal can be harnessed for depolarization of fermented medium for effective recovery and purification of industrial enzymes which can make the downstream processing in large-scale industrial bioprocesses more cost effective $[19,21]$. The result confirms activated charcoal as a good clarifying agent and unveils its potential as material for enzyme concentration.

\section{Conclusion}

In this study, glucoamylase was recovered from the fermentation broth by activated charcoal at $50^{\circ} \mathrm{C}$ for 20 minutes. After the elution process, a highly concentrated and purified glucoamylase was obtained in less than 30 minutes. This technique looks promising, cheap, and rapid in downstream processing of industrial enzymes.

\section{References}

[1] W. B. Da Silva and R. M. Peralta, "Purification and characterization of a thermostable glucoamylase from Aspergillus fumigatus," Canadian Journal of Microbiology, vol. 44, no. 5, pp. 493-497, 1998.

[2] S. O. Kareem, I. Akpan, and M. B. Osho, "Calotropis procera (Sodom apple) - a potential material for enzyme purification," Bioresource Technology, vol. 87, no. 1, pp. 133-135, 2003. 
[3] M. Sternberg, "Purification of industrial enzymes with polyacrylic acids," Process Biochemistry, vol. 11, no. 7, 1976.

[4] H. G. Vartak, M. V. Rele, M. Rao, and V. V. Deshpande, "A method for concentrating dilute solutions of macromolecules," Analytical Biochemistry, vol. 133, no. 1, pp. 260-263, 1983.

[5] K. M. Clark and C. E. Glartz, "Proteins fractionation by precipation with carboxy methyl cellulose," in Downstream Processing and Bioseparation, vol. 419 of American Chemical Society Symposium ASeries, pp. 170-187, 1990.

[6] E. Linne, N. Garg, R. Kaul, and B. Mattiasson, "Evaluation of alginate as a ligand carrier in affinity precipitant," Technology and Applied Chemistry, vol. 16, pp. 48-56, 1992.

[7] S. O. Kareem and I. Akpan, "Clarification of amylase extract from moldy bran with Imarsil," Enzyme and Microbial Technology, vol. 33, no. 2-3, pp. 259-261, 2003.

[8] A. E. Ochonogor and P. M. Ejikeme, "Adsorption potentials of Cinnarium schweinfurthi nutshell activated charcoal," Journal of Chemical Society of Nigeria, vol. 30, no. 2, pp. 91-95, 2005.

[9] M. L. Ulanovskij, I. D. Drozdnik, and A. I. Gordienko, "On interrelation of adsorption parameters of activated carbons," Journal of Chemical Society of Nigeria, no. 10, pp. 28-30, 1996.

[10] A. E. Ochonogor, "Indigo carmine removal from solutions using activated carbons of Terminalia catapa and Cinnarium schweinfurthi nutshell," Journal of Chemical Society of Nigeria, vol. 30, no. 2, pp. 88-90, 2005.

[11] L. Ye, N. N. Khandan, and F. G. Edwards, "Biological treatment of airstreams contaminated with organic vapors," Water Science and Technology, vol. 30, no. 7, pp. 71-74, 1994.

[12] D. O. Cooney, "Methods for treating poisoning and drug overdose," in Activated Charcoal in Medical Applications, D. O. Cooney, Ed., pp. 110-149, Marcel Dekker, New York, NY, USA, 1995.

[13] J. Hayashi, N. Yamamoto, T. Horikawa, K. Muroyama, and V. G. Gomes, "Preparation and characterization of highspecific-surface-area activated carbons from K2CO3-treated waste polyurethane," Journal of Colloid and Interface Science, vol. 281, no. 2, pp. 437-443, 2005.

[14] I. Akpan, M. J. Ikenebomeh, and H. W. Doelle, "Effect of carbon and nitrogen supplements to rice bran-based medium on amylase production by Rhizopus sp," Tropical Science, vol. 36, no. 3, pp. 166-173, 1996.

[15] G. L. Miller, "Use of dinitrosalicylic acid reagent for determination of reducing sugar," Analytical Chemistry, vol. 31, no. 3, pp. 426-428, 1959.

[16] A. L. Koch and S. L. Putnam, "Sensitive biuret method for determination of protein in an impure system such as whole bacteria," Analytical Biochemistry, vol. 44, no. 1, pp. 239-245, 1971.

[17] U. K. Laemmli, "Cleavage of structural proteins during the assembly of the head of bacteriophage T4," Nature, vol. 227, no. 5259, pp. 680-685, 1970.

[18] C. G. Kumar and P. Parrack, "Activated charcoal: a versatile decolorization agent for the recovery and purification of alkaline protease," World Journal of Microbiology and Biotechnology, vol. 19, no. 3, pp. 243-246, 2003.

[19] S. O. Kareem, Production and purification of thermostable glucoamylase of Aspergillus oryzae and Rhizopus oligosporus and their application in starch hydrolysis, Ph.D. thesis, University of Agriculture, Abeokuta, Nigeria, 2009.

[20] A. Pandey, "Glucoamylase research: an overview," Starch/ Starke, vol. 47, pp. 439-444, 1995.

[21] C. G. Kumar and H. Takagi, "Microbial alkaline proteases: from a bioindustrial viewpoint," Biotechnology Advances, vol. 17, no. 7, pp. 561-594, 1999. 

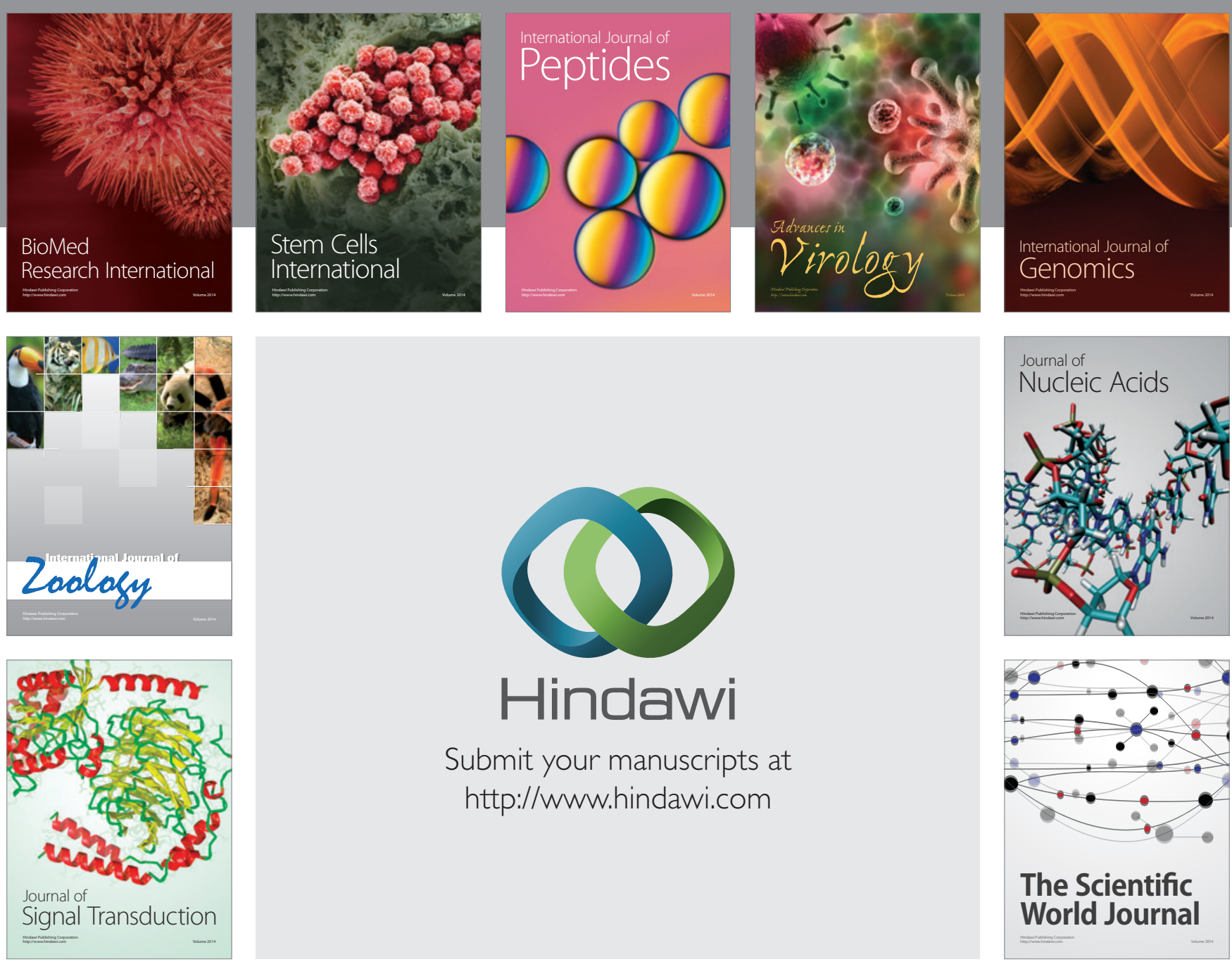

Submit your manuscripts at

http://www.hindawi.com
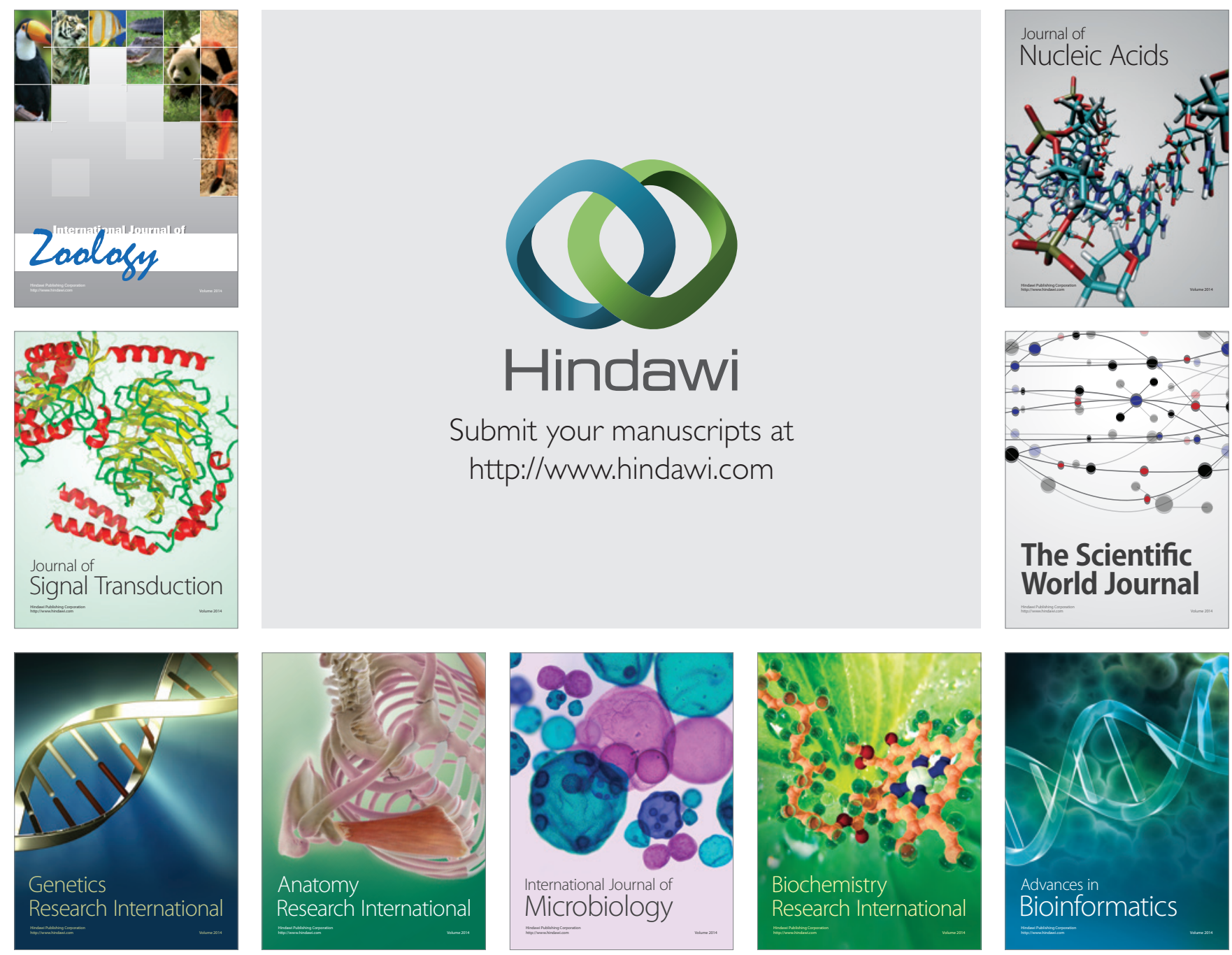

The Scientific World Journal
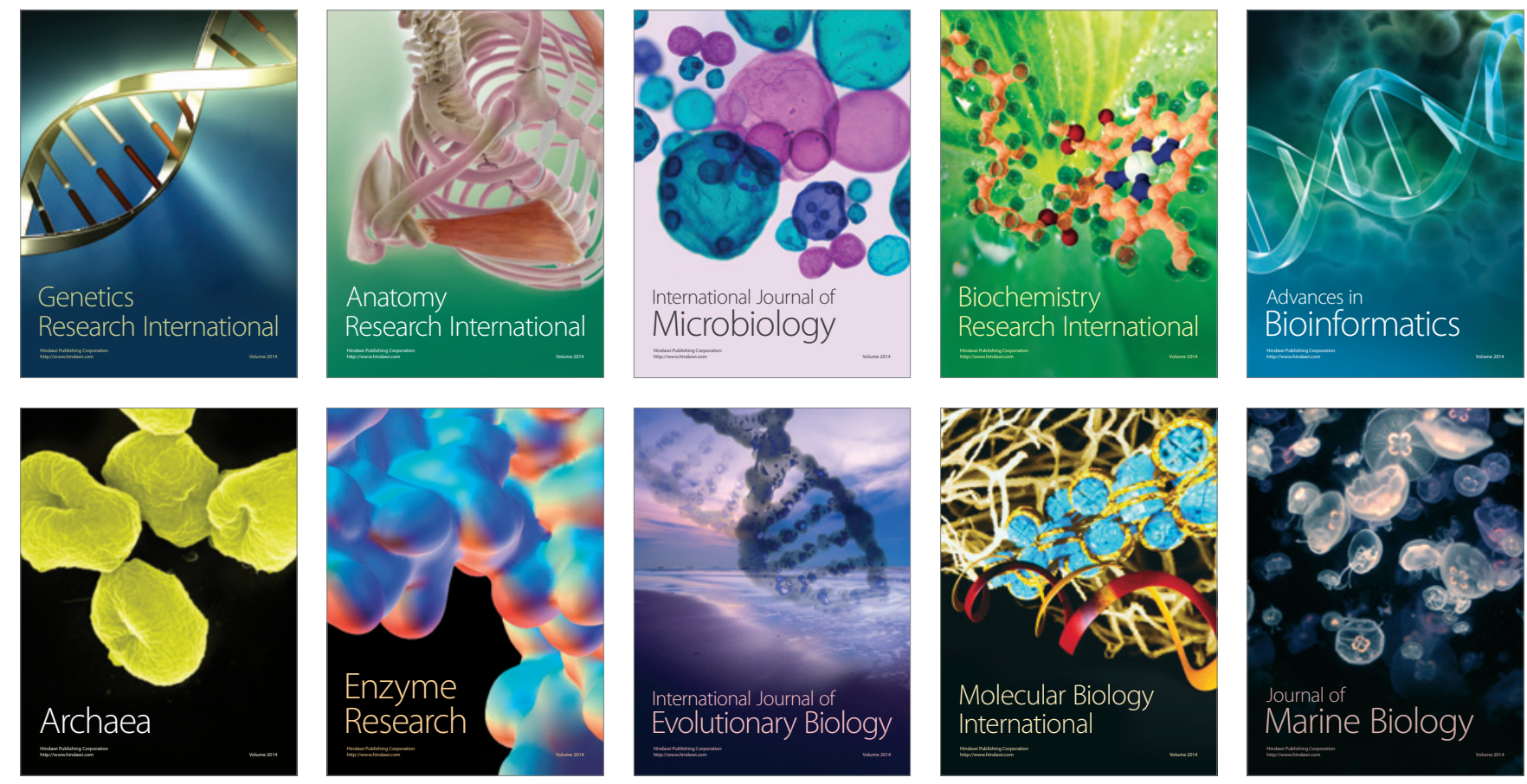